\title{
Occurrence of Pachycrepoideus vindemmiae (Rondani, 1875) (Hymenoptera: Pteromalidae) as a parasitoid of Megaselia scalaris (Loew, 1866) (Diptera: Phoridae) in Brazil
}

\author{
Marchiori, $\mathrm{CH}^{*}$. and Barbaresco, LF. \\ Centro Federal de Educação Tecnológica de Urutaí - UNED, \\ Br. 153, Km 633, CP 92, CEP 75650-000, Morrinhos, GO, Brazil \\ *e-mail: chmarchiori@yahoo.com.br \\ Received April 27, 2006 - Accepted August 11, 2006 - Distributed August 31, 2007
}

\begin{abstract}
Phoridae are small or minute flies easily recognized by their humpbacked appearance. The adults are fairly common in many habitats, but occur especially in decaying animal or vegetable matter. Some occur in fungi and some are internal parasitoids (Veríssimo, 1995; Andreotti et al., 2003) of various other insects.

Megaselia scalaris (Loew, 1866) (Diptera: Phoridae) is found in various environments and has a capacity to explore a great variety of ecological niches. The larvae can cause myiasis in different animals and in man (Robinson, 1975; Silva, 1999; Carvalho et al., 2000).

Pteromalidae are cosmopolitan in distribution and are one of the largest families of Chalcidoidea, containing over 3,000 recognized species in nearly 600 genera. The types of carnivorous behavior encountered in the family are very diverse, encompassing idiobiosis and koinobiosis, ectoparasitism and endoparasitism. There are solitary and gregarious species, and primary and secondary parasitoids (Gauld and Bolton, 1988; Hanson and Gauld, 1995). The hosts for Pteromalidae include Hemiptera, Neuroptera, Coleoptera, Lepidoptera, Diptera, Siphonaptera, Hymenoptera, Dermaptera and Homoptera. Pteromalidae attack eggs, larvae, pupae or, rarely, adults. The main contribution of pteromalids is their control over muscoid flies, especially the housefly and the stable fly (Gauld and Bolton, 1988; Hanson and Gauld, 1995).
\end{abstract}

Pachycrepoideus vindemmiae (Rondani, 1875) (Hymenoptera: Pteromalidae) is considered to be a solitary parasitoid that exercises control over a great number of Diptera in the families Anthomyiidae, Calliphoridae, Muscidae, Sarcophagidae, Tachinidae and Tephritidae. This species cosmopolitan has been found in North America and Africa (Rueda and Axtell, 1985; Marchiori et al., 2002; Marchiori et al., 2003; Carvalho et al., 2004).

The objective of this note is to report on the first occurrence of the parasitoid $P$. vindemmiae on M. scalaris in Brazil.

The study was conducted at the municipal slaughterhouse in the city of Tupaciguara, State of Minas Gerais $\left(18^{\circ} 35^{\prime} \mathrm{S}\right.$ and $\left.48^{\circ} 42^{\prime} \mathrm{W}\right)$, Brazil. The flies were attracted to traps consisting of dark-colored non-reflective cans, measuring $19 \mathrm{~cm}$ in height and $9 \mathrm{~cm}$ in diameter, with two slatted openings located in the lower third of the can to allow the flies to enter. The tops of the cans were coupled to nylon funnels that were open at the bottom, with their base pointing downwards. The funnels were wrapped in plastic bags so that the flies and parasitoids could be collected by removing these bags. Pieces of bovine kidney were used as the bait: placed inside the cans, on top of a layer of soil. Ten traps were used, and they were hung on trees at a height of one meter above the ground, two meters apart from each other. The insects collected were taken to the laboratory, killed using ethyl ether and kept in $70 \%$ alcohol for further identification. The contents of the traps were placed in plastic containers with a layer of sand to be used as the substratum for larval pupation. Fifteen days after removal from the field traps, the sand was sifted to extract the pupae, which were individually placed in gelatin capsules to await the emergence of the flies and/or parasitoids.

The prevalence of parasitism was calculated by the following formula: $\mathrm{P}=$ (parasite pupae/total pupae) $\mathrm{x}$ 100. The parasitoids were identified using the identification key put forward by Legner et al. (1976) and the identification of the hosts was based on McAlpine et al. (1981).

In September and October 2004, six specimens of $P$. vindemmiae were collected from 46 pupae of M. scalaris. The prevalence of parasitism observed was about $13.0 \%$.

Pachycrepoideus vindemmiae is considered a parasitoid of the pupae of a great number of Diptera, including species of Anastrepha, Calliphora, Ceratitis, Chrysomya, Drosophila, Fannia, Haematobia, Hylemya, Lucilia, Oxysarcodexia, Paratheresia, Phaenicia, Phormia, Poecilosomella, Peckia, Rhagoletis, Sarcophagula and Sarcodexia (Hanson and Gauld, 1995; Marchiori, 2000; Marchiori et al., 2000; Marchiori et al., 2002; Carvalho et al., 2003; Marchiori et al., 2003).

The fact that $P$. vindemmiae makes use of species of several Diptera genera favors their continual presence within the environment. This enhances their potential as biological control agents (Marchiori et al., 2002).

This paper registers the first occurrence of the parasitoid $P$. vindemmiae on pupae of $M$. scalaris in Brazil.

\section{References}

ANDREOTTI, R., KOLLER, WW., TADEI, WJ., PRADO, AP., BARROS JC., SANTOS, F. and GOMES, A., 2003. Ocurrence 
of the Megaselia scalaris (Loew, 1866) (Diptera, Phoridae) as a parasitoid of Boophilus microplus in campo Grande, MS, Brazil. Rev. Bras. Parasitol. Vet., vol. 12, no. 1, p. 46-47.

CARVALHO, LML., THYSSEN, PJ., LINHARES, AX. and PALHARES, FAB., 2000. A checklist of arthropods associated with pig carrion and human corpses in Southeastern Brazil. Mem. Inst. Oswaldo Cruz, vol. 95, no. 1, p. 135:138.

CARVALHO, AR., MELLO, RP. and D'ALMEIDA, JM., 2003. Microhimenópteros parasitóides de Chrysomya megacephala. Rev. Saúde Pública, vol. 37, no. 6, p. 810-812.

CARVALHO, A. R., D'ALMEIDA, J. M., MELLO, R. P., 2004. Mortalidade de larvas e pupas de Chrysomya megacephala (Fabricius) (Diptera: Calliphoridae) e seu parasitismo por microhimenópteros na cidade do Rio de Janeiro, RJ. Neotrop. Entomol., vol. 33, no. 4, p. 505-509.

GAULD, ID. and BOLTON, B., 1988. The Hymenoptera. Oxford University Press, Oxford, $5^{\text {th }}$ ed., $33 \mathrm{p}$.

HANSON, PE. and GAULD, ID., 1995. The Hymenoptera of Costa Rica. Oxford University Press, Oxford, 893p.

LEGNER, EE., MOORE, I. and OLTON, GS., 1976. Tabular keys \& biological notes to commom parasitoids of synanthropic Diptera breeding in accumulated animal wastes. Entomol. News, vol. 87, no. 5/6, p. 113-144.

MARCHIORI, CH., 2000. Parasitóides de estágios imaturos de dípteros sinantrópicos coletados em vários ambientes em Itumbiara-GO. Acta Scientiarum, vol. 22, no. 3, p. 655-66.

MARCHIORI, CH., OLIVEIRA, AMS., MARTINS, FF., BOSSI, FS. and OLIVEIRA, AT., 2000. Ocorrência de moscas frugívoras (Diptera: Tephritidae e Lonchaeidae) e seus parasitóides em Itumbiara-GO. Arq. Inst. Biol., vol. 67, no. 1, p.139-14.

MARCHIORI, CH., PEREIRA, LA., SILVA FILHO, OM. and SILVA, LC., 2002. Pachycrepoideus vindemmiae (Rondani) (Hymenoptera: Pteromalidae) as parasitoid of Diptera, in Brazil. Arq. Bras. Med. Vet. Zootec., vol. 54, no. 6, p. 665-667.

MARCHIORI, CH., PEREIRA, LA. and SILVA FILHO, OM., 2003. Primeiro relato do parasitóide Pachycrepoideus vindemmiae (Rondani) (Hymenoptera: Pteromalidae) parasitando pupas de Sarcodexia lambens Wiedemann (Diptera: Sarcophagidae). Cien. Rur., vol. 33, no. 1, p. 73-175.

McALPINE, JF., PETERSON, BV., SHEWEELL, GE., TESKEY, HJ., VOCKROTH, JR. and WOOD, DM., 1981. Manual of neartic Diptera. Research Branche Agriculture, Otawa, $1332 \mathrm{p}$.

ROBINSON, WH., 1975. Megaselia (M.) scalaris (Diptera: Phoridae) associated with laboratory cockroach colonies. Proc. Entomol. Soc. Wash., vol. 77, no. 2, p. 384-390.

RUEDA, LM. and AXTELL, RC., 1985. Guide to common species of pupal parasites (Hymenoptera: Pteromalidae) of the house fly and other muscoid flies associated with poultry and livestock manure. Technical Bulletin, vol. 278, p. 1-88.

SILVA, JS., PRADO, AP., RODRIGUES, RR., LOPES, CRM. and GODOY, WAC., 1999. Megaselia scalaris (Diptera: Phoridae) causing myiasis in Crotalus durissus terrificus (Serpentes: Viperidae) in Brasil. J. Med. Entomol., vol. 36, no. 2, p. 630-631.

VERISSIMO, CJ., 1995. Inimigos naturais do carrapato parasita dos bovinos. Agro. Catarinense, vol. 8, no. 1, p. 35-37. 